\title{
ILLINOIS STATE GEOLOGICAL SURVEY RADIOCARBON DATES III
}

\author{
DENNIS D. COLEMAN \\ Illinois State Geological Survey, Urbana, Illinois 61801
}

The following date list includes all samples processed from December 1969 through November 1970 at the Illinois State Geological Survey Radiocarbon Dating Laboratory. The benzene liquid scintillation technique was used, following the method of Noakes, Kim, and Stipp (1965), and Noakes, Kim, and Akers (1967). Detailed sample preparation procedures used in this laboratory have been reported by Kim and Ruch (1969), and Kim, Ruch, and Kempton (1969).

All ages are calculated using a $\mathrm{C}^{14}$ half-life of 5568 years and the NBS oxalic acid standard as reference. Errors $(1 \sigma)$ reported account only for uncertainties in activity measurements of the sample, standard, and backgrounds. If the calculated error is less than 200 years, a minimum error of \pm 200 years is assigned. No corrections have been made for isotopic fractionation or atmospheric $\mathrm{C}^{14}$ fluctuations.

Samples ISGS-33 through ISGS-38 were dated by S. M. Kim and the remainder by the author. Chao $\mathrm{Li}$ Liu assisted in sample preparation. All samples submitted were screened prior to acceptance by an Isotopic Analysis Committee consisting of J. P. Kempton (chairman), Charles Collinson, R. E. Bergstrom, D. D. Coleman, and J. C. Frye.

\section{GEOLOGIC SAMPLES}

\section{A. United States}

\section{ISGS-33. Lake Michigan Core 146-2}

Varved lake sediment from core sample $32 \mathrm{~km} \mathrm{E}$ of Waukegan, Illinois (42 $21^{\prime} 48^{\prime \prime} \mathrm{N}$ Lat, $87^{\circ} 25^{\prime} 0^{\prime \prime} \mathrm{W}$ Long). Organic-rich layers from 26 to $106 \mathrm{~cm}$ depth were combined. Coll. 1969 by D. L. Gross, J. A. Lineback, and H. V. Leland; subm. by D. L. Gross, Illinois State Geol. Survey.

\section{ISGS-36. Lake Michigan Cores 143-2 and 144-2}

Organic-rich clay from 2 cores 52 and $45 \mathrm{~km} \mathrm{E}$ of Waukegan, Illinois $\left(42^{\circ} 21^{\prime} 48^{\prime \prime} \mathrm{N}\right.$ Lat, $87^{\circ} 10^{\prime} 48^{\prime \prime} \mathrm{W}$ Long, and $42^{\circ} 21^{\prime} 48^{\prime \prime} \mathrm{N}$ Lat, $87^{\circ}$ $15^{\prime} 36^{\prime \prime} \mathrm{W}$ Long). Organic-rich layers from 35 to $65 \mathrm{~cm}$ depth in 2 adjacent cores. Coll. 1969 by D. L. Gross, J. A. Lineback, and H. V. Leland; subm. by D. L. Gross.

General Comment (D.L.G.): samples date top of lacustrine sediment sequence (Lake Michigan Formation) in S Lake Michigan, indicating that most of Lake Michigan Formation was deposited late in Wisconsinan stage during glacial melting, and that there is relatively little Holocene sediment in this part of lake. See Gross et al. (1970) and Lineback, Ayer, and Gross (1970). 


\section{ISGS-37. Tuscola Borrow Pit section}

Peaty silt from upper $8 \mathrm{~cm}$ of $30 \mathrm{~cm}$ unit in Douglas Co., NE1/4 SE $1 / 4$ SW $1 / 4$ Sec. 26, T.16N, R.8E, $1.6 \mathrm{~km} \mathrm{NE}$ of center of Tuscola, Illinois $\left(39^{\circ} 48^{\prime} 32^{\prime \prime} \mathrm{N}\right.$ Lat, $88^{\circ} 16^{\prime} 1^{\prime \prime} \mathrm{W}$ Long). From peaty silt unit at $8 \mathrm{~m}$ depth, below Woodfordian gray silty till. Coll. 1969 by D. L. Gross and W. H. Johnson; subm. by D. L. Gross. Comment (D.L.G.): from stratigraphic position of Robein Silt. Most organic silt underlying Woodfordian tills in E-central Illinois date 20,000 to 27,000 yr в.P.

\section{Edwardsville Section series}

ISGS-39. ED-1, wood fragments 18,050 B.c.

\section{ISGS-45. ED-2, gastropod shells}

$21,350 \pm 320$

Both samples from same horizon in Madison Co., NW1/4 NE1/4 SE1/4 Sec. 29, T.4N, R.8W, $7.7 \mathrm{~km}$ SW of Edwardsville, Illinois ( $38^{\circ} 46^{\prime} 10^{\prime \prime}$ $\mathrm{N}$ Lat, $90^{\circ} 00^{\prime} 30^{\prime \prime} \mathrm{W}$ Long). From organic silt (Robein Silt?) below Peoria Loess and above Roxana Silt. Coll. 1969 and subm. by A. M. Jacobs, Illinois State Geol. Survey. Comment (A.M.J.): from stratigraphic position of Robein Silt; dates deposit during early Woodfordian substage. Wood and shell dates agree.

\section{ISGS-46. Shelby County Moraine section}

$$
\begin{aligned}
& 21,400 \pm 1000 \\
& 19,450 \text { в.c. }
\end{aligned}
$$

Peat and wood fragments in accretion-gley from Shelby Co., NE1/4 $\mathrm{SE} 1 / 4 \mathrm{SW} 1 / 4$ Sec. 8 , T.11N, R.4E, $1.6 \mathrm{~km} \mathrm{E}$ of center of Shelbyville, Illinois $\left(39^{\circ} 24^{\prime} 36^{\prime \prime} \mathrm{N}\right.$ Lat, $88^{\circ} 46^{\prime} 54^{\prime \prime} \mathrm{W}$ Long). From upper $30 \mathrm{~cm}$ of $1.5 \mathrm{~m}$ thick accretion-gley. Three separate fractions dated: acid-soluble, base-soluble, and insoluble fractions. As all 3 dates were in statistical agreement, an average value is reported. Coll. 1969 by D. L. Gross and W. H. Johnson; subm. by D. L. Gross. Comment (W.H.J.): dates uppermost portion of accretion-gley (Berry Clay Member of Glasford Formation) overlying Vandalia Till Member of Glasford Formation and indicates that deposition of Berry Clay Member continued into early Woodfordian. ISGS-26, 20,000 \pm 200 , and ISGS-32, 21,300 \pm 500 (R., 1970 , v. 12 , p. 507), from top and bottom, respectively, of overlying Robein Silt, indicate no time break between Berry Clay Member and Robein Silt deposits (Johnson et al., 1971).

Vandalia Core series, Pittsburg Basin

ISGS-47. J-1, 200 to $210 \mathrm{~cm}$ depth

ISGS-53. J-2, 225 to $230 \mathrm{~cm}$ depth 
$\mathrm{N}$ Lat, $89^{\circ} 11^{\prime} 30^{\prime \prime} \mathrm{W}$ Long). From Equality Formation, 4 to $5 \mathrm{~m}$ above Hagarstown Member of Glasford Formation; see Jacobs and Lineback (1969), Jacobs (1970), and Grüger (1969). Coll. 1969 by A. M. Jacobs and H. E. Wright; subm. by A. M. Jacobs. Comment (A.M.J.): interval dated by ISGS-47 marks appearance of spruce in local pollen rain and increase in relative abundance of expandable clay minerals in response to encroachment of Woodfordian ice front. Interval dated by ISGS-53 marks maximum of pine in local pollen rain and maximum of illite and kaolinite in clay fraction. Related to previously pub. Vandalia Core series (R., 1970, v. 12, p. 505).

\section{Volo Bog series}

Site is in Lake Co., SW1/4 SE1/4 NE1/4 Sec. 28, T.45N, R.9E, $2.4 \mathrm{~km}$ $\mathrm{N}$ of Volo, Illinois (42. $20^{\prime} \mathrm{N}$ Lat, $88^{\circ} 11^{\prime} \mathrm{W}$ Long). Coll. 1970 by M. R. McComas; subm. by J. P. Kempton, Illinois State Geol. Survey.

\section{ISGS-49. Volo Bog \#1}

Reed and sedge peat from edge of bog at base of peat overlying sand and gravel, $1.5 \mathrm{~m}$ below surface. Comment (J.P.K.): from local and regional data, date implies peat accumulated along edge of bog in response to rising water levels.

\section{ISGS-50. Volo Bog \#2}

$460 \pm 310$

Decayed Sphagnum peat from base of floating mat, ca. $1.5 \mathrm{~m}$ below surface. Comment (J.P.K.): sample dated to show development rate of floating mat, but small size prevents definite conclusions.

\section{ISGS-52. Clear Creek section}

Wood fragments in till from Putnam Co., NW1/4 NW $1 / 4$ NE $1 / 4$ Sec. 19, T.31N, R.1W, $8 \mathrm{~km}$ ENE of Henry, Illinois $\left(41^{\circ} 09^{\prime} \mathrm{N}\right.$ Lat, $89^{\circ} 16^{\prime}$ W Long). From base of $7.3 \mathrm{~m} \mathrm{sec}$. of blue-gray till overlying organic silt. Coll. 1964 by J. C. Frye and H. B. Willman; subm. by J. C. Frye, Illinois State Geol. Survey. Comment (J.C.F.): dates assoc. fossil snail fauna and underlying till as Altonian or older.

\section{Hughes Peat Bed series}

Site in Linn Co., SWl $1 / 4 \mathrm{SW}_{1 / 4} \mathrm{SW}_{1 / 4}$ Sec. 2, T.83N, R.6W, $5 \mathrm{~km} \mathrm{E}$ of Marion, Iowa $\left(42^{\circ} 01^{\prime} \mathrm{N}\right.$ Lat, $91^{\circ} 31^{\prime} \mathrm{W}$ Long).

\section{ISGS-38. Hughes Peat Bed \#1}

$4940 \pm 200$

Peat from brain case of Bison occidentalis, overlain by 1 to $1.5 \mathrm{~m}$ peat; underlain by ca. $1.5 \mathrm{~m}$ peat. Coll. 1969 by H. A. Semken, Jr.; subm. by S. A. Hall, Univ. of Iowa. Comment (S.A.H.): dates Hughes bison as youngest Bison occidentalis. 
ISGS-41. Hughes Peat Bed \#2

Wood from Picea stump, id. by B. F. Kukachka and R. C. Koeppen, Forest Products Lab., Madison, Wisconsin. Coll. 1969 and subm. by S. A. Hall. Comment (S.A.H.): date is possibly minimum for Picea-dominated arboreal vegetation indicated by pollen analysis of core segments stratigraphically beneath dated stump. Base of Picea-Cyperaceae pollen zone dated $11,880 \pm 250$ yr B.P. (I-5102, unpub.).

$9340 \pm 200$

ISGS-55. Hughes Peat Bed \#3

7390 в.c.

Peat from basal $5 \mathrm{~cm}$ of peat bed. Coll. 1970 and subm. by S. A. Hall. Comment (S.A.H.): date is minimum for beginning of peat formation in Hughes deposit. Analysis of same horizon $25 \mathrm{~m} \mathrm{E}$ of dated sample indicates Quercus-Ulmus pollen zone.

ISGS-56. Hughes Peat Bed \#4

$5640 \pm 540$

Bone collagen from Bison occidentalis, 0.6 to $1 \mathrm{~m}$ from present surface of peat bed. Coll. 1969 by H. A. Semken, Jr.; subm. by S. A. Hall. Comment (S.A.H.): confirms ISGS-38 and supports Hughes bison as youngest Bison occidentalis reported.

\section{Rocky Fork Cut series}

Wood in gravel from Franklin Co., SW1/4 SE1/4 Sec. 2, T.1N, R.16W, $1.6 \mathrm{~km} \mathrm{E}$ of Gahanna, Ohio (40 $1^{\prime} 6^{\prime \prime} \mathrm{N}$ Lat, $82^{\circ} 51^{\prime} 9^{\prime \prime} \mathrm{W}$ Long). Coll. and subm. by R. P. Goldthwait, Ohio State Univ.

ISGS-40. 68-9-14A

From Lockborne Gravel, at bottom edge of upper oxidized zone. Coll. 1968.

ISGS-57. 70-4-4

From Lockborne Gravel, at bottom of coarse boulder gravel just above contact with Rocky Fork Till. Sample believed contaminated in lab.; therefore minimum age is assigned. Coll. 1970.

General Comment (R.P.G.): dates indicate Altonian or older for early interstadial deposits.

ISGS-42. Olive Moraine, C-47
$\mathbf{2 1 , 0 8 0} \pm \mathbf{2 0 0}$
$\mathbf{1 9 , 1 3 0 \text { B.c. }}$
Wood from till in Highland Co., $5 \mathrm{~km} \mathrm{NNE}$ of Hillsboro, Ohio
$\left(39^{\circ} 14^{\prime} 56^{\prime \prime} \mathrm{N}\right.$ Lat, $83^{\circ} 34^{\prime} 52^{\prime \prime}$ W Long). From Boston till at $5 \mathrm{~m}$
depth, $1.2 \mathrm{~m}$ below yellow oxidized zone, underlain by paleosol in
Illinoian gravel. Coll. 1969 by T. E. Rosengreen; subm. by R. P. Gold-
thwait. Comment (T.E.R.): date establishes age of Mt. Olive Moraine
and time when late Wisconsinan glacier of Scioto Lobe first reached
terminal position of initial advance into S Ohio.


ISGS-44. Fall Creek, D-36

$20,910 \pm 240$

18,960 в.с.

Wood from till in Highland Co., $10 \mathrm{~km}$ NNE of Hillsboro, Ohio (39 $15^{\prime} 44^{\prime \prime} \mathrm{N}$ Lat, $83^{\circ} 32^{\prime} 52^{\prime \prime} \mathrm{W}$ Long). From lower, unoxidized portion of Boston till; overlain by Darby Till bearing modern soil and underlain by Sangamon paleosol in silt. Coll. 1969 by T. E. Rosengreen; subm. by R. P. Goldthwait. Comment (T.E.R.): identifies Boston till as late Wisconsinan, not early Wisconsinan as hypothesized on basis of soil development.

ISGS-59. Blinco Branch, C-58

$>37,770$

Wood from till in Highland Co., $4.3 \mathrm{~km} \mathrm{E}$ of Rainsboro, Ohio

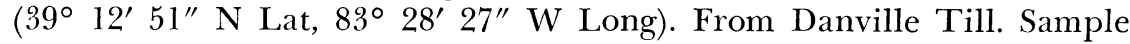
believed contaminated in ISGS lab., therefore minimum age is assigned. Coll. 1970 by T. E. Rosengreen; subm. by R. P. Goldthwait. Comment (T.E.R.): date indicates that Danville Till is older than late Wisconsinan and rectifies a former age of $25,300 \pm 600$ B.P. (I-4797, unpub.) for wood believed contaminated in field.

\section{B. Other Countries}

\section{Sao Paulo Basin series}

ISGS-34. Sao Paulo City site, RP-2

ISGS-43. Sao Paulo City site, RP-1

$>44,600$

Wood from alluvium of Tietê and Pinheiros Rivers, within Sao

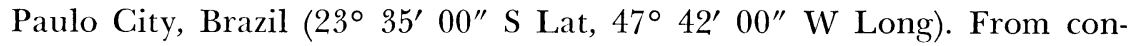
tinental sediments near SW border of Sao Paulo Basin. Coll. 1969 by Kenitiro Suguio; subm. by J. C. Mendes, Univ. of Sao Paulo. Comment (K.S.): wood-bearing alluvium represents phase of fluvial sedimentation in tectonically active area. Dates indicate site was still tectonically unstable 44,600 yr B.P.

ISGS-54. Vietnam 48-6

$2700 \pm 200$ 750 B.C.

Organic-rich soil from Long An Prov., $10 \mathrm{~km} \mathrm{~S}$ of Long An, Vietnam $\left(10^{\circ} 30^{\prime} \mathrm{N}\right.$ Lat, $106^{\circ} 22^{\prime} \mathrm{E}$ Long). Sample from buried soil horizon, $90+$ cm depth. Coll. 1963 by T. D. Phu; subm. by E. H. Tyner, Univ. of Illinois. Comment (E.H.T.): from humic paleosol horizon very high in total sulfur compared to sulfur content of overlying soil horizons; indicative of very brackish environment during formative period. May represent soil formation in period between Crane Key and Pelham Bay periods of emergence (Fairbridge, 1961) when sea stands were 2 to $3 \mathrm{~m}$ below present datum.

II. ARCHAEOLOGIC SAMPLES

\section{Rodgers Shelter series}

From Benton Co., SW1 14 SW1/4 NE1/4 Sec. 33, T.39N, R.22W, 19

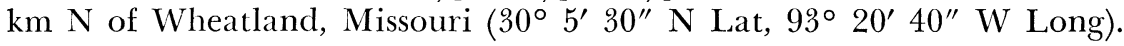


Coll. 1968 by R. B. McMillan, Illinois State Mus., Springfield, Illinois; subm. by M. D. Thompson.

\section{ISGS-35. Rodgers Shelter, 5315}

Carbonized wood from colluvial cultural layer designated Stratum 2 in Rodgers sequence. Comment (R.B.M.): dates end of deposition of Stratum 2.

\section{ISGS-48. Rodgers Shelter, 7799 and 8259}

$10,530 \pm 650$

Carbonized wood from alluvial clay near base of Stratum 1 in Rodgers sequence. Comment (R.B.M.): dates Dalton complex occupation early in terrace-building sequence.

\section{ISGS-51. Brynjulfson Cave \#1}

$1400 \pm 200$

Charcoal particles in soil from Boone Co., SW1/4 NE1/4 SW $1 / 4$ Sec. 16, T.47N, R.12W, $19 \mathrm{~km} \mathrm{~S}$ of Columbia, Missouri $\left(38^{\circ} 51^{\prime} 7^{\prime \prime} \mathrm{N}\right.$ Lat, $92^{\circ} 16^{\prime} 50^{\prime \prime} \mathrm{W}$ Long). Between 3 and $5 \mathrm{~m}$ from cave entrance, ca. $1 \mathrm{~m}$ above floor, mixed with soil and bone debris. Coll. 1969 by P. W. Parmalee and R. D. Oesch; subm. by P. W. Parmalee, Illinois State Mus., Springfield, Illinois. Comment (P.W.P.): date younger than estimated age of faunal material, but correlates with time when cave was infrequently used by Indians of Late Woodland (Boone focus) culture; charcoal particles may be residue of their fires.

\section{REFERENCES}

Fairbridge, R. E., 1961, Eustatic changes in sea level, in: V. 4, Physics and Chemistry of the Earth: New York, Pergamon Press, p. 99-185.

Cross, D. L., et al., 1970, Preliminary stratigraphy of unconsolidated sediments from the southwestern part of Lake Michigan: Illinois Geol. Survey Environmental Geol. Note 30, 20 p.

Grüger, E. 1969, Die Entwicklung der Vegetation in Süd-Illinois seit dem Ende der vorletzen Kaltzeit (abs.): 8th Cong. INQUA, Paris, 1969, Résumés des Communs., p. 90 .

Jacobs, A. M., 1970, Persistence of lake basins in southern Illinois, U.S.A., from late Illinoian time to present: Rev. Géog. Physique et Géol. Dynamique (2), v. 12, fasc. 2, p. 137-142.

Jacobs, A. M. and Lineback, J. A., 1969, Glacial geology of the Vandalia, Illinois, region: Illinois Geol. Survey Circ. 442, 23 p.

Johnson, W. H. et al., 1971, Glacial drift of the Shelbyville Moraine at Shelbyville, Illinois: Illinois Geol. Survey Circ. 459, 22 p.

Kim, S. M. and Ruch, R. R., 1969, Illinois State Geological Survey radiocarbon dates I: Radiocarbon, v. 11, p. 394-395.

Kim, S. M., Ruch, R. R., and Kempton, J. P., 1969, Radiocarbon dating at the Illinois State Geological Survey: Illinois Geol. Survey Environmental Geol. Note 28, 19 p.

Lineback, J. A., Ayer, N. J., and Gross, D. L., 1970, Stratigraphy of unconsolidated sediments in the southern part of Lake Michigan: Illinois Geol. Survey Environmental Geol. Note 35,35 p.

Noakes, J. E., Kim, S. M., and Akers, L. K., 1967, Recent improvements in benzene chemistry for radiocarbon dating: Geochim. et Cosmochim. Acta, v. 31, p. 10941096.

Noakes, J. E., Kim, S. M., and Stipp, J. J., 1965, Chemical and counting advances in liquid scintillation radiocarbon dating: 6th internatl. conf. radiocarbon and tritium dating Proc., Conf-650652, p. 68-98. 